\title{
The Effectiveness of the Deviation of Intercultural Communication Interaction Setting Informal Education for Ethnic Papuan Students in Learning at the State University of Malang
}

\author{
Zulkarnain \\ Department of Non-formal Education \\ State University of Malang, Indonesia \\ zulkarnain.fip@um.ac.id
}

\begin{abstract}
The communication behavior of Papuan students who are passive, quiet and lacking in self-confidence makes them experience difficulties in building social relations with Javanese ethnic friends so that the interaction of intercultural communication cannot work effectively. Therefore, the presence of a Javanese counterpart who bridges the interaction of communication between Papuan students and Javanese ethnic students is very necessary to help them to enter the social environment or the social relations of students in the classroom or outside the classroom. The purpose of this study is the feasibility of using the model and guidance on the interaction of intercultural communication interactions in informal education settings for ethnic Papuan ADIK Program students in taking S1 studies at the State University of Malang (UM). The experimental design in this study is a quasi-experimental type. The experimental research of the research subject is not randomly named quasi-entrepreneurial. Measuring the interaction of intercultural communication in the informal education of ethnic Papuan students in taking S1 studies at UM used an experimental design of One Group Pretest-Posttest Design. The conclusions of the study are as follows: (1) the results of limited trials of models and mentoring from the companion of communication interaction in the informal education setting in the classroom to ethnic Papuan students with an average score at pretest of $77.3 \%$ interaction between intercultural communication for ethnic Papuan students and posttest results $85.4 \%$; (2) from the findings in the field, there are a number of things to consider in relation to the usefulness of the model and guide to interaction between intercultural communication, informal education settings for ethnic Papuan students. Study at UM is based on field studies that are very practical models and can be applied by accompanying lecturers and students field study well; and (3) this guidebook has met the criteria of acceptability from experts, users and research subjects. Lecturers always motivate students to accompany interaction between intercultural communication in informal education settings.
\end{abstract}

Keywords: mentoring, cultural communication, informal education

\section{INTRODUCTION}

The presentations of students at PTN at this time through National Selection Enter State Universities (SNMPTN) through written examinations that are competition with a fairly high selection stringency, making it difficult to implement the affirmation principle. In addition, other problems are the absence of students taking undergraduate studies at various state universities to adapt in the first year. The lack of success in following the teaching and learning process and the completion of the Higher Education Affirmation (ADIK) student study are often the result of the absence of an early adaptation period that introduced changes in the learning system from middle school to university.

The Ministry of Research, Technology and Higher Education (Kemristekdikti) held a program to accelerate human resource development for regions that are considered still lagging behind in the education sector, namely the Higher Education Affirmation program. The aim of the ADIK program is to facilitate young people from regions that are still lagging behind in the field of education to get the opportunity to pursue higher education throughout the archipelago in Indonesia. Through this ADIK program Kemristekdikti provides rotating scholarships from one region to another that are left behind in the field of education to native sons and daughters who have graduated from high school, vocational high school or madrasah aliyah.
Educational delivery must help indigenous Papuan children to open their access to knowledge. This will help them to naturally grow and develop their welfare in various aspects of life. Education will elevate their degrees and help to get to know and absorb universal values and avoid thinking narrowly and fragmatically. Every human being cannot escape from the interaction of communication with other individuals in their daily lives, therefore communication interaction is very important in everyday social life, but there are also individuals who do not have good communication interaction skills and cannot be understood by other individuals when in speaking, especially if those involved in communication have different cultural backgrounds, the difficulty to understand and produce effective communication becomes a huge obstacle because of the cultural differences that cause errors in understanding the message received by someone when communicating.

Initial interactions and differences between cultures will greatly affect an individual or someone to connect with someone or another person who is different in culture or someone will end the relationship. This is because the greater the cultural differences that exist, then the individual or someone can avoid the tendency to judge others in a hurry based on the assessment of someone, therefore it is necessary to be flexible to improve our opinions or judgments towards others. 
In the interaction of intercultural communication, individuals always try to maximize the results of interaction, therefore people will interact with other people or other individuals that they expect to have a positive impact, therefore intercultural communication is very difficult for individuals to avoid communication interactions, preferring to speak and communicate with a friend who has similarities or similarities in character to that person, it will narrow the perspective and view of others towards other people who have cultural differences.

Culture gives identity to a group of people, how to identify cultural aspects that make a group of people very different. The aspects of crocodile characteristics according to Mulyana (2001) include: communication and language, clothing and appearance, food and eating habits, time and awareness of time, appreciation and recognition, relationships, values and norms, sense of self and space, mental processes and learning, as well as beliefs and attitudes. Informal education is education that takes place naturally without us being aware of occurring in our daily environment and informal education takes place in families and communities. Informal education is education is the process of helping students or students develop their potential.

The interaction of intercultural communication in informal education in the classroom in shaping the positive character of students according to Helmawati (2017) includes: (1) getting used to smiles, greetings, and greetings; (2) getting used to respecting, respecting; (3) getting used to obeying the rules (rules in class); (4) familiarizing concentration during the learning process; (5) getting used to being responsible; (6) getting used to learning (studying); (7) getting used to being honest; (8) getting used to maintaining cleanliness and neatness in dress; and (9) get used to being humble and always grateful.

The talent of each individual is different from one another, the ability to capture lessons is also different, the level of business will vary, then the time factor needed by different individuals will also be different to master the course material. Therefore there are a number of factors that influence the effectiveness of learning and learning outcomes as follows, namely: (1) time available to complete a lecture material that has been determined, for example one semester; (2) efforts made by individuals to master the lecture material; (3) the talent of someone who is very individual; and (4) the quality of learning or the level of clarity of teaching, which is related to the explanatory strategies used, the timing of the teaching.

The ability of students to get opimal benefits from the entire teaching and learning process they are facing. Tracing the background of learning difficulties faced by students must look at the determinants of actualization of learning process events. The communication behavior of Papuan students who are passive, quiet, and lacking in self-confidence makes them experience difficulties in building social relations with Javanese ethnic friends so that the interaction of intercultural communication cannot work effectively.
Therefore, the presence of a Javanese counterpart who bridges the interaction of communication between Papuan students and Javanese ethnic students is very necessary to help them to enter the social environment or the social relations of students in the classroom or outside the classroom. The purpose of this study is the feasibility of using the model and guidance on the interaction of intercultural communication interactions in informal education settings for ethnic Papuan ADIK Program students in taking S1 studies at the State University of Malang.

\section{METHODS}

The experimental design in this study was a quasi-experimental type, because it did not randomize the selection of subjects for the trial group. Campbell and Stanley (in Hasan, 1994) explained that the experimental research whose research subjects were determined not randomly was called quasientrepreneurial (quasi exprimental). Measuring the interaction of intercultural communication in the informal education of ethnic Papuan students in taking S1 studies at UM used an experimental design of One Group Pretest-Posttest Design.

According to Sugiyono (2012), this experimental design before mentoring was carried out, was given a pretest and after being given assistance, post-test was conducted with the same ethnic Papuan students. The type of data used in this development research is quantitative obtained a pre-test and post-test questionnaire to see the effectiveness of the model and guidance. Knowing the suitability of the mentoring guide is processed with quantitative descriptive methods. According to Arikunto (2009) states that descriptive statistics serve to provide an overview of an object under study as it is.

\section{RESULTS}

Presentation of Data from the Pre-test Assessment and Post-test of Mentoring Students in the Classroom

The results of the assessment of 11 (eleven) participants in the Interaction of Inter-cultural Communication Interaction between Papuan Students in the classroom obtained the data as in the Table 1 as follows.

Table 1

Pre-test results and Post-test Participants in the Classroom

\begin{tabular}{|c|l|c|c|c|c|}
\hline \multirow{2}{*}{ No } & \multirow{2}{*}{ Responden } & \multicolumn{2}{|c|}{ Pre-test } & \multicolumn{2}{c|}{ Post-test } \\
\cline { 3 - 6 } & & $\sum$ & $\mathbf{\%}$ & $\sum$ & \% \\
\hline 1 & Responden 1 & 51 & 6.8 & 56 & 7.4 \\
\hline 2 & Responden 2 & 56 & 7.4 & 49 & 6.5 \\
\hline 3 & Responden 3 & 44 & 5.8 & 54 & 7.2 \\
\hline 4 & Responden 4 & 56 & 7.4 & 66 & 8.8 \\
\hline 5 & Responden 5 & 54 & 7.2 & 54 & 7.2 \\
\hline 6 & Responden 6 & 64 & 8.5 & 54 & 7.2 \\
\hline 7 & Responden 7 & 56 & 7.4 & 57 & 7.6 \\
\hline 8 & Responden 8 & 51 & 6.8 & 54 & 7.2 \\
\hline 9 & Responden 9 & 43 & 5.7 & 50 & 6.6 \\
\hline 10 & Responden 10 & 55 & 7.3 & 67 & 8.9 \\
\hline 11 & Responden 11 & 53 & 7.0 & 61 & 8.1 \\
\hline \multicolumn{7}{|c}{ Total } & $\mathbf{5 8 3}$ & $\mathbf{7 7 . 3}$ & $\mathbf{6 2 2}$ & $\mathbf{8 2 . 7}$ \\
\hline
\end{tabular}




\section{Delivering Opinions during Group Discussion}

The results of the questionnaire recapitulation of respondents in the pre-test and post-test of ethnic Papuan students studying at UM based on the interaction of intercultural communication in the learning process of expressing opinions in the class were obtained as follows (Figure 1). Based on the results of the bar diagram (Figure 1) on the question of mentoring the interaction of intercultural communication in the learning process expressing opinions in the class can be explained that when implementing the Pre-Test obtained a score of $72 \%$ while the Post-Test obtained $80 \%$ results. There is an increase of $8 \%$ of the coaching that has been done.

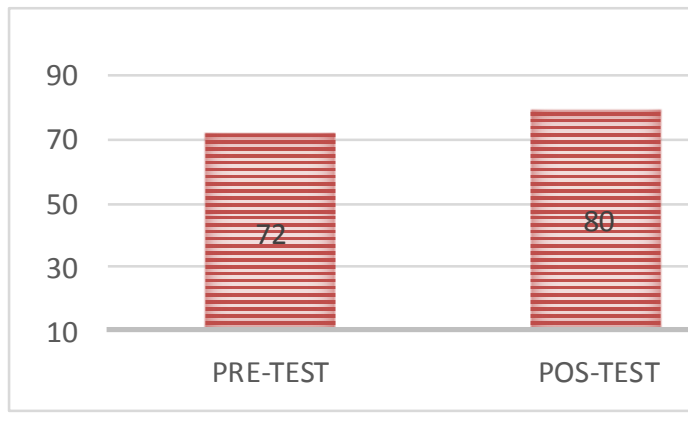

Figure 1

Delivering Opinions during Group Discussion

\section{Group Discussions and Presentation of Lecture Material}

The results of the questionnaire recapitulation of the respondents pre-test and post-test of ethnic Papuan students studying at UM were based on mentoring the interaction of intercultural communication during group discussion and the percentage of lecture material in the class obtained the following results (Figure 2). Based on the results of the bar diagram (Figure 2) on mentoring the interaction of intercultural communication during group discussions and the percentage of lecture material in the class can be explained that at the time of the Pre-Test the score was $56 \%$ while the Post-Test obtained $72 \%$. There is an increase of $16 \%$ from the coaching that has been done.

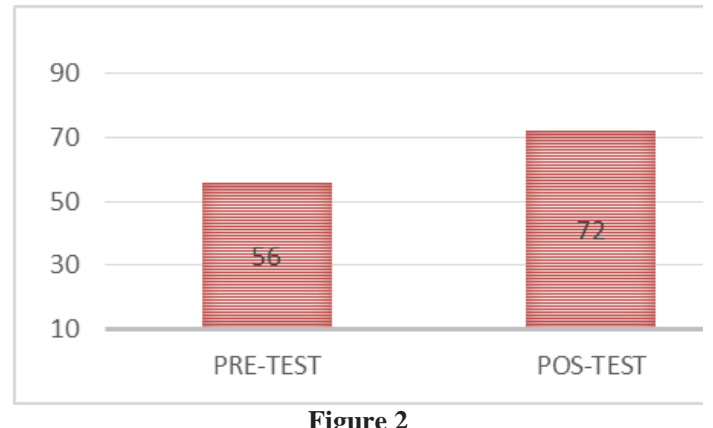

Group Discussions and Presentation of Lecture Material

\section{When the Lecturer Asks}

The results of the questionnaire recapitulation of the pre-test respondents and the post-test of ethnic Papuan students studying at UM were based on mentoring the interaction of intercultural communication when the lecturers were having the following results in the class (Figure 1). Based on the results of the bar diagram (Figure 3), mentoring the interaction of intercultural communication when the lecturer has a lecture in the classroom can be explained that at the time of the Pre-Test the score was $63 \%$ while the Post-Test obtained $67 \%$. There is an increase of $4 \%$ from the coaching that has been done.

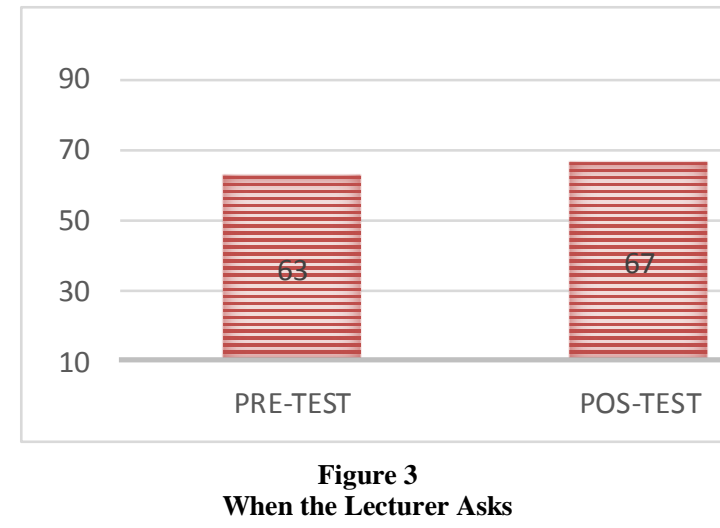

\section{Ask if there is Material that has not been Understood}

The results of the questionnaire recapitulation of the respondents in the pre-test and post-test of ethnic Papuan students studying at UM based on mentoring the interaction of intercultural communication if there is material that has not been understood in the classroom, the following results are obtained (Figure 4). Based on the results of the bar diagram (Figure 4), mentoring the interaction of intercultural communication if there is material that has not been understood in the classroom, it can be explained that during the Pre-Test, it was $63 \%$ while the Post-Test obtained $69 \%$. There is an increase of $6 \%$ from the coaching that has been done.

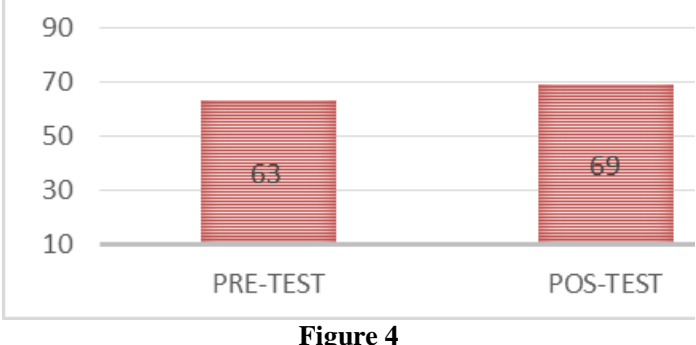

Ask if there is Material that has not been Understood

\section{Doing Tasks Given Up-to-Date Lecturers}

The questionnaire recapitulation results of the respondents in the pre-test and post-test of ethnic Papuan students studying at UM were based on mentoring the interaction of intercultural communication in based on mentoring the interaction of intercultural communication in carrying out the assignments given by the lecturer until the results were obtained as follows (Figure 5). Based on the results of the bar diagram (Figure 5) on mentoring the interaction of intercultural communication in carrying out the tasks given by the lecturer to completion, it can be explained that at the time of the Pre-Test the score was 
$65 \%$ while the Post-Test obtained $74 \%$. There is an increase of $9 \%$ of the coaching that has been done.

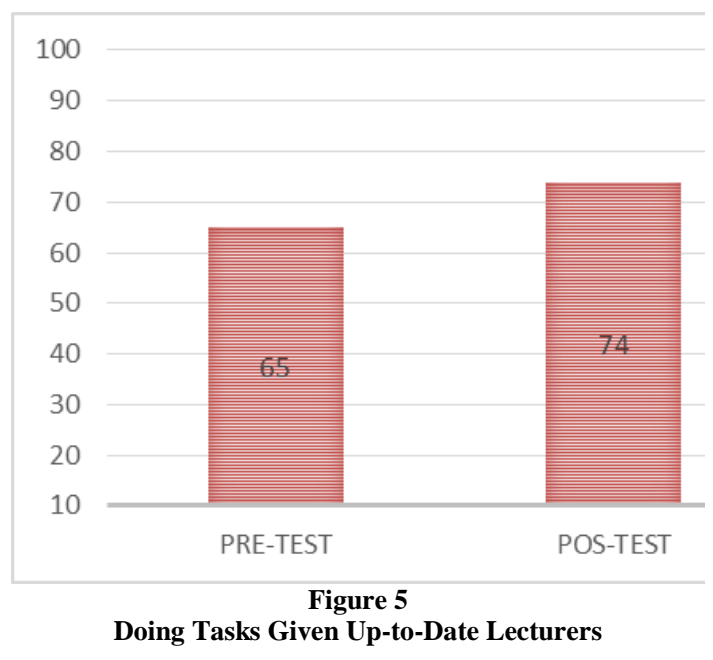

Deliver Greetings and Greetings to Friends in Class

The questionnaire recapitulation results of the respondents in the pre-test and post-test of ethnic Papuan students who study at UM based on the assistance of intercultural communication interaction in based on the assistance of intercultural communication interaction in conveying greetings and greetings to friends in class are obtained as follows (Figure 6). Based on the results of the bar diagram (Figure 6), mentoring the interaction of intercultural communication in based on the accompaniment of intercultural communication interaction in conveying greetings and greetings to friends in class can be explained that at the time of the Pre-Test the score was $81 \%$ while the Post-Test obtained $96 \%$. There is an increase of $15 \%$ from the coaching that has been done.

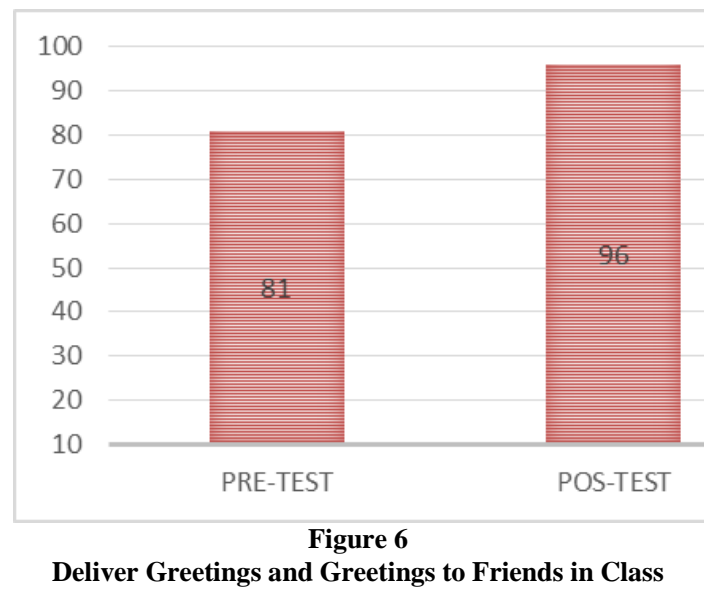

\section{Respect Each Other in Class}

The results of the questionnaire recapitulation of the respondents pre-test and post-test of ethnic Papuan students studying at UM based on the accompaniment of the interaction of communication with mutual respect for friends in class were obtained as follows (Figure 7). Based on the results of the bar diagram (Figure 7), mentoring the interaction of intercultural communication with each other to respect friends in class can be explained that at the time of the Pre-Test the score was $85 \%$ while the Post-Test obtained $98 \%$. There is an increase of $13 \%$ from the coaching that has been done.

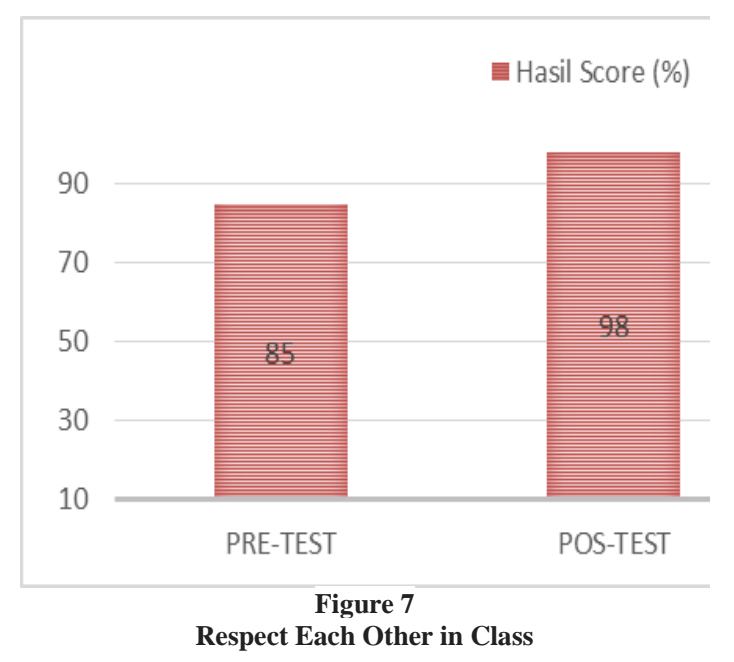

\section{Respect Friends in Class}

The results of the questionnaire recapitulation of the pre-test respondents and the post-test of ethnic Papuan students who studied at UM based on the interaction of intercultural communication interaction valued friends in the class obtained the following results (Figure 8). Based on the results of the bar diagram (Figure 8), mentoring the interaction of intercultural communication to appreciate friends in class can be explained that when the Pre-Test was carried out, it was $83 \%$ while the Post-Test obtained $94 \%$. There is an increase of $11 \%$ of the coaching that has been done.

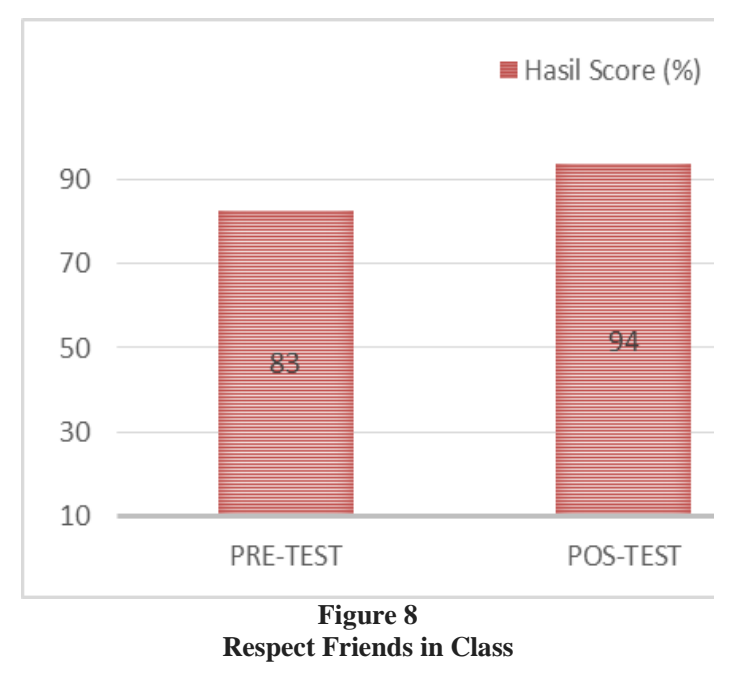

\section{Obeying the Rules in the Class}

The results of the questionnaire recapitulation of respondents in the pre-test and post-test of ethnic Papuan students who study at UM based on the interaction of intercultural communication assistance appreciate obeying the rules (rules) in the class obtained the following results (Figure 9). Based on the results of the bar chart (Figure 9), respecting obeying the rules (rules) in the class can be explained that when the Pre-Test was carried out, the score was $81 \%$ while the Post-Test obtained $87 \%$. There is an increase of $6 \%$ from the coaching that has been done. 


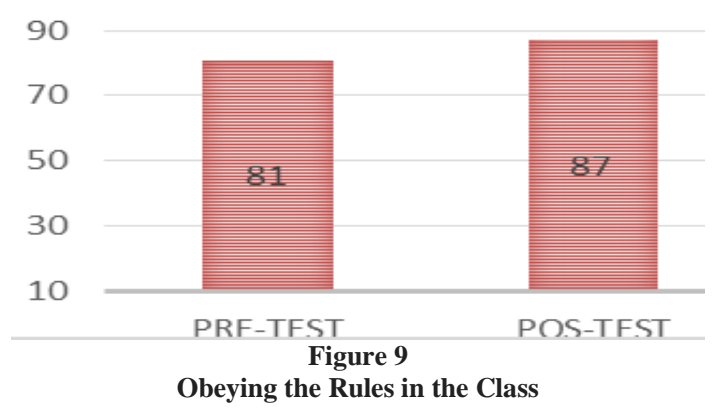

Concentration during the Learning Process in Class

The results of the questionnaire recapitulation of respondents in the pre-test and post-test of ethnic Papuan students studying at UM were based on mentoring the interaction of intercultural communication in concentration when the learning process in the classroom obtained the following results (Figure 10). Based on the results of the bar diagram (Figure 10) in question X10 it can be explained that at the time of the Pre-Test the value of $80 \%$ was obtained while the Post-Test obtained $81 \%$. There is an increase of $1 \%$ of the coaching that has been done.

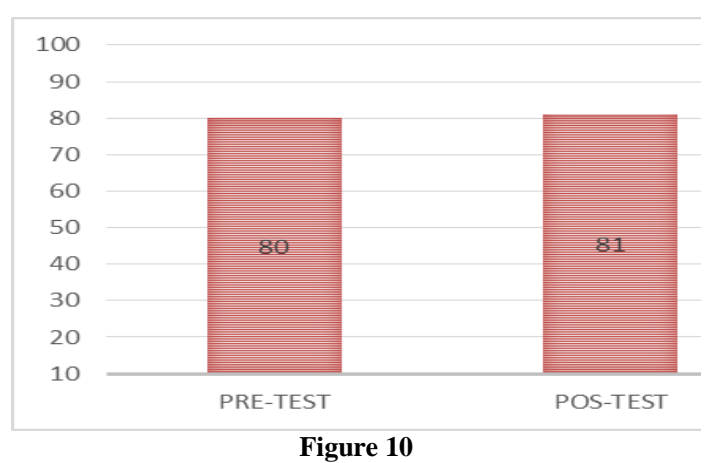

Concentrations during the Learning Process in Class

\section{Honest in Doing Tasks in Class}

The results of the questionnaire recapitulation of respondents pre-test and post-test of ethnic Papuan students studying at UM based on mentoring the interaction of intercultural communication honestly in carrying out the tasks in the learning process in the classroom obtained the following results (Figure 11). Based on the results of the honest bar diagram (Figure 11) in working on assignments in class, it can be explained that at the time of the Pre-Test the score was $78 \%$ while the Post-Test obtained $85 \%$. There is an increase of $7 \%$ from the coaching that has been done.

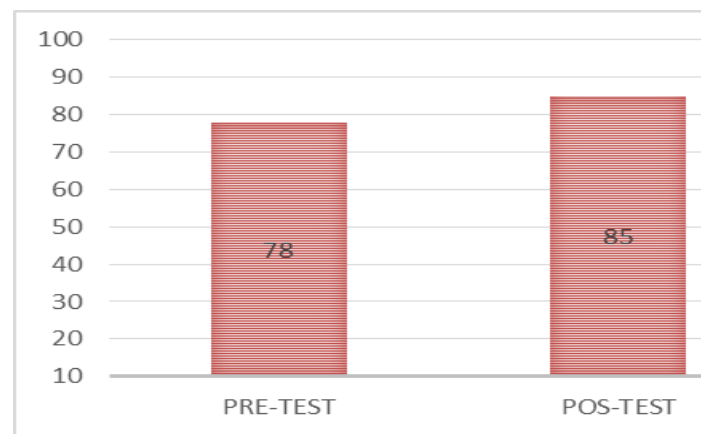

Figure 11

Honest in Doing Tasks in Class

\section{Maintain Cleanliness in Class}

The results of the questionnaire recapitulation of respondents in the pre-test and post-test of ethnic Papuan students studying at UM based on mentoring the interaction of intercultural communication honestly in maintaining cleanliness in the classroom was obtained as follows (Figure 12). Based on the results of the bar diagram (Figure 12), mentoring the interaction of honest intercultural communication in maintaining cleanliness in the classroom can be explained that during the Pre-Test implementation, it was $78 \%$ while the Post-Test obtained $87 \%$. There is an increase of $9 \%$ of the coaching that has been done.

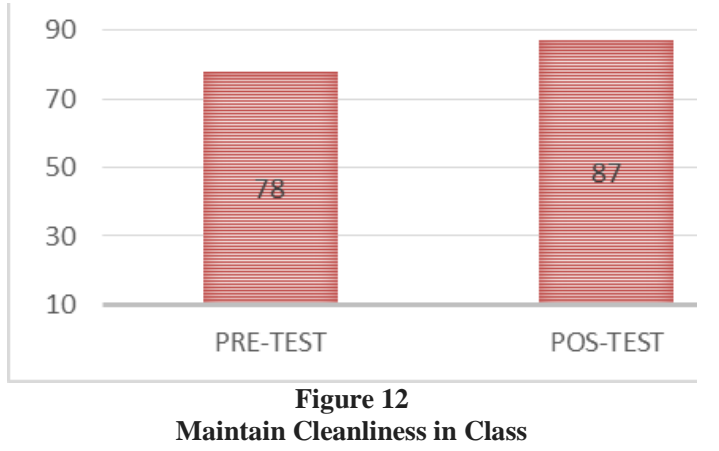

\section{Dress Neatly While in Class}

The results of the questionnaire recapitulation of the pre-test respondents and the post-test of ethnic Papuan students studying at UM were based on mentoring the interaction of intercultural communication dressed neatly when in the class obtained the following results (Figure 13). Based on the results of the bar diagram (Figure 13), mentoring the interaction of intercultural communication dressed neatly when in class can be explained that when the Pre-Test was carried out, the score was $89 \%$ while the Post-Test obtained $89 \%$. There is an increase of $0 \%$ from the coaching that has been done.

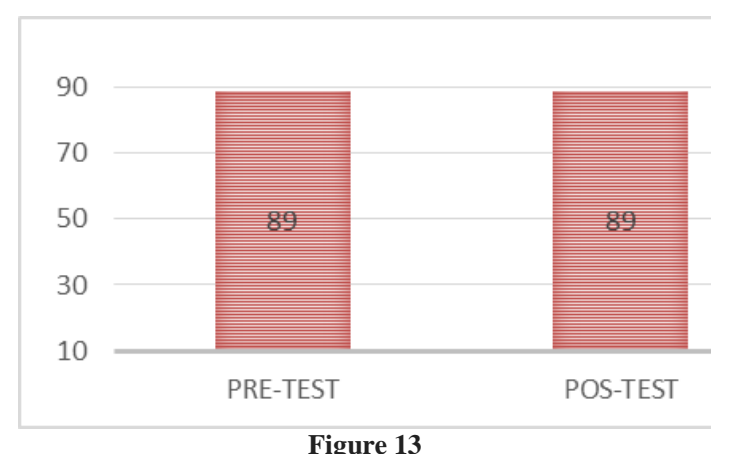

Dress Neatly While in Class

\section{Humility When Communicating in Class}

The results of the questionnaire recapitulation of the pre-test respondents and the post-test of ethnic Papuan students who studied at UM based on the assistance of the interaction of humble intercultural communication when communicating in class were obtained as follows (Figure 14). Based on the results of the bar diagram (Figure 14), mentoring the interaction of humble intercultural communication when 
communicating in class can be explained that at the time of the Pre-Test the score was $74 \%$ while the PostTest obtained $85 \%$. There is an increase of $11 \%$ of the coaching that has been done.

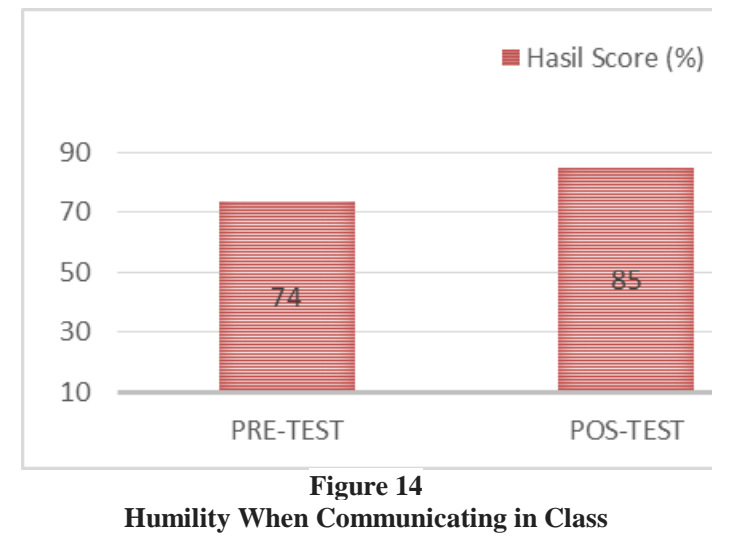

IV. DISCUSSION

Based on these data, it can be seen that there has been an increase in the application of assistance for intercultural communication interactions for ethnic Papuan undergraduate students studying at UM before mentoring and after providing assistance in the interaction of intercultural communication in the classroom during the learning process. In line with the results of these studies it can be explained that the interaction of communication and culture are two concepts that cannot be separated from the two contexts.

Attention to communication and culture lies in the variety of steps and ways humans communicate both individually with individuals, individuals with groups, and groups with social groups. The focus of communication and cultural studies also includes how to explore meaning, patterns of action and how these meanings and patterns are articulated in social groups that involve human interaction (Liliweri, 2007). Based on the results of the analysis that has been carried out, it can be illustrated that the interaction behavior of Papuan students in the UM campus environment is influenced by the cultural, sociocultural and psychobudic backgrounds brought by each individual.

The influence of the cultural background seen in the communication behavior of Papuan students is: (1) language, which appears in the form of dialect, intonation, tone, and speed of speech; (2) a collective culture which is characterized by a tendency to gather with other ethnic groups in this case is more likely to carry out activities in groups, meaning that group solidarity is more prioritized than personal responsibility; and (3) loose time orientation (polycronics) so that the completion of work or tasks is often.

Being late is not even done at all, and prefers activities that are habitual compared to challenging new things. Viewed from the perspective of the sociocultural aspects, the social norms or values that exist in indigenous Papuans are not apparent in the interaction behavior of Papuan students. Their communication interaction behavior is more influenced by positive norms or values that are generally applicable and universal religious teachings, such as love, help, tolerance, and so on.

\section{CONCLUSION}

The results of the limited trial model and mentoring from the companion of communication interaction in the informal education setting in the classroom to ethnic Papuan students with an average score at pretest of $77.3 \%$ of intercultural communication interaction for ethnic Papuan students and posttest results of $85.4 \%$. From the findings in the field, there are several things to consider in relation to the usefulness of the model and guidance on the interaction of intercultural communication in informal education settings for ethnic Papuan students.

Study at Malang State University based on field studies, the models and guidelines are very practical and are able to be applied by lecturers and field study assistants well. This guidebook has met the criteria of acceptability from experts, users and research subjects. Lecturers always motivate students to accompany interaction between intercultural communication in informal education settings.

\section{REFERENCES}

[1] Arifah. 2014. Afirmasi Pendidikan: Pintu masuk Gapai Kesetaraan Layanan Pendidikan. Dikbud Magazine, January.

[2] Borg, W. R., \& Gall, M. D.2003. Educational Research An Introduction. New York: Longman.

[3] Chaney, L. H., and Martin, J. S. 2004. Intercultural Communication. Dubuque, Iowa: Brown.

[4] Daryanto. 2010. Ilmu Komunikasi. Bandung: Satu Nusa.

[5] Devito, J. A. 1996. Human Communication. USA: Haper Collins Publisher Inc.

[6] Helmawati. 2017. Pendidikan Karakter Sehari-hari. Jakarta: Remadja Rosdakarya.

[7] Gudykunst, W. B., and Kim, Y. Y. 1997. Communicating with Strangers: An Approach to Intercultural Communication. USA: McGraw Hill.

[8] Gudykunst, W. B. 1983. Intercultural Communication Theory. Baverly Hills, Calivornia: Sage Publications.

[9] Glay, B. 1996. Pembangunan Irian Jaya dalam Perspektif Agama, Budaya, dan Antropologi. Buletin Deiyai.

[10] Koentjoroningrat. 1994. Papua Membangun Masyarakat Majemuk. Jakarta: Jambatan.

[11] Liliweri, A. 2002. Dasar-Dasar Komunikasi Antarbudaya. Yogyakarta: Pustaka Pelajar.

[12] Liliweri, A. 2007. Makna Budaya dalam Komunikasi Antarbudaya. Yogyakarta: LKIS Yogyakarta.

[13] Miles, M. B., and Huberman, A. M. 1992. Analisis Data Kualitatif. Jakarta: UI Press.

[14] Mulyana, D. 2000. Ilmu Komunikasi Suatu Pengantar. Bandung: Remaja Rosdakarya.

[15] Narendra, P. 2008. Metodologi Riset Komunikasi. Yogyakarta: Balai Pengkajian Pengembangan Informasi Pusat Kajian Media dan Budaya Populer.

[16] Rekhmat, J. 2007. Psikologi Massa. Bandung: Remaja Rosdakarya.

[17] Rakhmat, J. 2005. Psikologi Komunikasi. Jakarta: Remadja Rosdakarya.

[18] Samovar, L. A., and Porter, R. E. 2010. Communication Betwen Cultures. Beltmon CA: Wardsworth, Inc. 
[19] Samavor, L. A., Porter, R. E., and Jain, N. C. 1981. Understanding Intercultural Communication. California: Wadsworth Publishing Company.

[20] Suparlan, P. 1994. The Diversity of Cultures in Irian Jaya. The Indonesian Quarttely, 22(2), 170-182. 